WellBeing International

WBI Studies Repository

$9-2000$

\title{
Monitoring cattle behavior and pasture use with GPS and GIS
}

L. W. Turner

University of Kentucky

M. C. Udal

University of Kentucky

B. T. Larson

University of Kentucky

S. A. Shearer

University of Kentucky

Follow this and additional works at: https://www.wellbeingintlstudiesrepository.org/mmfarm

Part of the Agribusiness Commons, Animal Studies Commons, and the Geographic Information Sciences Commons

\section{Recommended Citation}

Turner, L. W., Udal, M. C., Larson, B. T. and Shearer, S. A. 2000. Monitoring cattle behavior and pasture use with GPS and GIS. Can. J. Anim. Sci. 80: 405-413. DOI: https://doi.org/10.4141/A99-093

This material is brought to you for free and open access by WellBeing International. It has been accepted for inclusion by an authorized administrator of the WBI Studies Repository. For more information, please contact wbisr-info@wellbeingintl.org.

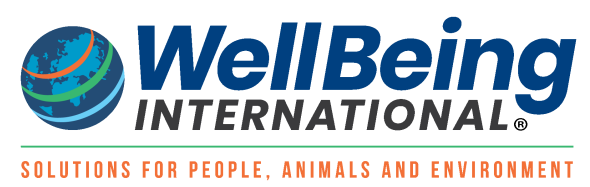




\title{
Monitoring cattle behavior and pasture use with GPS and GIS ${ }^{1}$
}

\author{
L.W. Turner², M.C. Udal'2, B.T. Larson ${ }^{3}$, and S.A. Shearer ${ }^{2}$ \\ ${ }^{2}$ Departments of Biosystems \& Agricultural Engineering, and ${ }^{3}$ Department of Animal Sciences, University of \\ Kentucky, Lexington, KY 40546 USA (e-mail: Iturner@bae.uky.edu). Received 24 September 1999, \\ accepted 2 May 2000.
}

\begin{abstract}
Turner, L. W., Udal, M. C., Larson, B. T. and Shearer, S. A. 2000. Monitoring cattle behavior and pasture use with GPS and GIS. Can. J. Anim. Sci. 80: 405-413. Precision agriculture is already being used commercially to improve variability management in row crop agriculture. In the same way, understanding how spatial and temporal variability of animal, forage, soil and landscape features affect grazing behavior and forage utilization provides potential to modify pasture management, improve efficiency of utilization, and maximize profits. Recent advances in global positioning system (GPS) technology have allowed the development of lightweight GPS collar receivers suitable for monitoring animal position at 5-min intervals. The GPS data can be imported into a geographic information system (GIS) to assess animal behavior characteristics and pasture utilization. This paper describes application and use of GPS technology on intensively managed beef cattle, and implications for livestock behavior and management research on pasture.
\end{abstract}

Key words: Livestock behavior, electronics, grazing, forage, global positioning system, geographic information system

Turner, L. W., Udal, M. C., Larson, B. T. et Shearer, S. A. 2000. Surveillance continue du comportement des bovins et de l'utilisation du pâturage au moyen des systèmes GPS et GIS. Can. J. Anim. Sci. 80: 405-413. L'agriculture de précision est déjà utilisée pour améliorer la maîtrise de la variabilité dans les cultures en lignes. La compréhension des effets de la variabilité spatio-temporelle qui affecte les animaux, les fourrages, le sol et le paysage sur les comportements au pâturage et sur l'utilisation des herbages permettrait de modifier la conduite du pâturage, en plus d'en améliorer l'utilisation et de maximiser les profits. Les progrès récents dont bénéficie la technologie du système de positionnement global (GPS) nous ont valu la mise au point de colliers receveurs de GPS autorisant la surveillance des déplacements des animaux à intervalles de 5 minutes. Les données GPS peuvent être intégrées dans un système d'information géographique (GIS) pour évaluer les caractères du comportement animal et de l'utilisation du pâturage. Nous décrivons l'application et l'utilisation de la technologie GPS dans la gestion intensive des bovins à viande et nous en examinons les incidences pour la recherche sur le comportement et sur la gestion des animaux au pâturage.

Mots clés: Comportement, électronique, pâturage, fourrage, système de positionnement global, système d'information géographique

Global positioning system monitoring can provide researchers with efficient and accurate information on grazing behavior. Previous research focused on tracking animals using data gathered by observation. Recent advances in GPS technology have allowed the development of lightweight collar receivers suitable for monitoring animal position at 5min intervals. Data can be imported into a GIS to assess animal behavior characteristics and pasture utilization. Precision animal location recording allows researchers to evaluate pasture utilization, animal performance, and behavior. Researchers may assess the merits of pasture or paddock shapes and sizes, fence designs, grazing systems, forage

${ }^{1}$ The information reported in this paper, No. 00-05-74, was developed in connection with a project of the University of Kentucky Agricultural Experiment Station and is published with the approval of the Director.

Presented at the 1999 annual meeting of the Canadian Society of Animal Science, Charlottetown, Prince Edward Island. composition and availability, location of shade, water, and supplements, and other variables that affect beef cattle operations.

The objectives of this article are: 1) to review previous tracking technology; 2) to explain GPS animal monitoring; 3 ) to describe GPS tracking collar application for beef cattle; and 4) to discuss pasture livestock behavior and management research implications.

Cattle Grazing Behavior and Pasture Distribution Significant investigation of cattle behavior, grazing distribution, and forage utilization has been conducted previously. Research has focused on cattle preferences, improving grazing efficiency by various management techniques, and grazing consequences in riparian zones.

Abbreviations: CEP, circular error probable; DGPS, differential GPS; GIS, geographic information system; GPS, global positioning system; PTT, platform transmitter terminals; VHF, very high frequency 
Hart et al. (1993) [15-minute intervals during daylight hours, colored collars, locations on a 100-m grid] evaluated grazing systems (continuous and rotational) and pasture size ( 24 vs. 207 ha) effects on cattle behavior, distribution and weight gain. Langbein and Nichelmann (1993) visually observed behavior of free-ranging Holstein-Friesian and Siboney de Cuba breeds in a tropical climate. Proportions of time spent grazing, lying, standing, and using shade were evaluated between breeds. Heat stress effects such as reduced feed intake, increased water intake, increased respiration rate, decreased conception rate, and increased body temperature have been studied by Buffington et al. (1983), Collier et al. (1981), and Blackshaw and Blackshaw (1994). Smith et al. (1992), using binoculars, observed cattle during daylight hours at 15-min intervals in a continuously grazed pasture and recorded time spent in channel, floodplain, and upland areas to assess riparian grazing. Marlow et al. (1987) proposed pasture rest or rotation and limiting riparian vegetation cattle use to reduce stream bank degradation. Stream bank degradation resulted from combinations of soil moisture, stream flow, and cattle use, but not solely cattle presence. Owens et al. (1991) identified green herbage availability, grass quantity, brush abundance, remoteness from roads and water, and proximity to fences as major factors affecting utilization of pasture in a continuous grazing system. Radio telemetry tracking has been used to record cattle rangeland distribution effects by water availability and terrain slope (Pinchak et al.1991).

This research enhanced the understanding of cattle behavior/distribution and utilization in various pasture systems. Pasture design and management improvements have led to greater efficiencies and higher returns. However, gathering data is the most difficult aspect in all studies. Automation of data gathering and accuracy improvement continue to be major goals of research in this field

\section{Previous Tracking Methods}

Free-ranging animal tracking has previously shown low animal-location-per-time predictability. Early methods relied on human observation of natural (color patterns) or artificial features (colored collar or tag). Problems included observer fatigue and associated error, study area accuracy and physical limitations, external factors (weather and light), and observer proximity effects on animals.

\section{VHF Radio Signal Tracking}

Very high frequency (VHF) technology (battery-powered transmitter, receiver, and recorder) has been commercially available since the late 1950s (Rodgers et al. 1996). A radio transmitter attached to the sought-out animal generates a unique signal to identify, remotely locate, and home-in on the animal for observation. Modern transmitters are small and versatile, which has allowed the tracking of many small animals like mice, birds and ghost crabs (Mech 1983). Gibb et al. (1998) have monitored bunk attendance of feedlot cattle. Location fixes and accuracy depend on mobile researcher (ground or air), terrain, visibility, discomfort, and fatigue. Without a visual sighting, errors have exceeded 500 m (Rodgers et al. 1996).

\section{ARGOS Data Collection and Location System}

The ARGOS Data Collection and Location System records environmental data including ecological, meteorological, hydrologic, and oceanographic information (Argos 1984). ARGOS consists of: 1) earth-based platform transmitter terminals (PTT); 2) polar orbiting Tiros-N satellites; and 3) ground-based satellite tracking station network and; 4) communication links that transfer data to processing centers. All weather, wide-range location collars (with battery-powered PTT, $1.5 \mathrm{~kg}$ ) may support simultaneous measurements (temperature, motion and pressure sensors). Animals studied include wolf and bear (Ballard 1997); polar bear, caribou, musk oxen, brown bear, gray wolf, moose, pacific walrus, Dall sheep, elk, and mule deer (Harris et al. 1990); elephant (Tchamba et al. 1995); whale [Mate et al. (1983), cited by Harris et al. (1990)]; and small birds [Fuller et al. (1984) cited by Harris et al. (1990)]. The average location error of wolf and bear was $577 \mathrm{~m}$ and $1110 \mathrm{~m}$, respectively (Ballard 1997). ARGOS system errors equal VHF methods, where errors can exceed $0.5 \mathrm{~km}$ (Rodgers et al. 1996). Animal-attached PTT collar location information is provided without human intervention. The position is fixed regardless of weather conditions, season, or time of day. Data are available in remote locations within $8 \mathrm{~h}$ of satellite overpass (Tchamba et al. 1995) and PTT are less labor intensive than VHF tracking methods. Ballard (1997), in a 3-yr study of wolves, reported obtaining location fixes with relatively high frequency (once every $2 \mathrm{~d}$ ) at one-third the cost of VHF telemetry.

\section{Global Positioning System (GPS) For Animal Monitoring}

Navstar GPS (Navigation System with Timing and Ranging) is operated by the US Department of Defense. Initially designed for the military, users obtain position fixes via a constellation of carefully monitored earth-orbiting satellites. The GPS system components are: 1) space segment -24 satellites arranged in orbits where five to eight satellites are visible from any point on earth at any time and generate/transmit precisely timed radio signals (Dana 1997); 2) control segment - network of ground-based stations to monitor satellite information (health status and time, and satellite location) to ensure correct operation of the system; 3) user segment - user-community receivers that convert satellite signals into location estimates. Apart from receiver cost, processing equipment or software, there is no subscription cost involved with using basic GPS signals.

Accuracy of GPS Technology. While GPS uses extremely accurate timing mechanisms and state-of-art electronics, it is subject to errors, notably:

- Satellite clock errors - system depends on accuracy of satellite clocks.

- Satellite position errors - known as ephemeris errors.

- Receiver errors - accuracy of clock.

- Atmospheric errors - propagation rates of radio waves change as they move through ionosphere and troposphere.

- Multi path errors - radio signal reflection off large objects. 
- Selective availability (SA) errors - degraded accuracy of clock and ephemeral correction information is biggest component of error for civilian users.

This deliberate and unpredictable waver of the satellite clock (controlled by the military) can be switched on or off at will. The SA results in decreased accuracy of location and is intended to prevent more accurate positioning capabilities from falling into enemy hands. This inaccuracy can be vastly improved with differential GPS (DGPS) correction procedure. A stationary receiver (base station) is placed at a surveyed mark and takes position readings simultaneous with a roving receiver. The stationary receiver calculates location positions that will not correspond exactly to the surveyed mark due to the error sources. However, since the stationary marker has known coordinates, the receiver can calculate the magnitude of errors involved. If the roving receiver is relatively close to the base station (within approximately $50 \mathrm{~km}$ ), many of the same errors also apply to the roving receiver and can be removed from location fixes. In this way, an accuracy of at least $5 \mathrm{~m}$ horizontal is readily obtainable.

Absolute errors are expressed as radial distance of error location from true location. Circular error probable (CEP) is circle radius that contains the stated percentile of points around a true location (Rempel et al. 1995; Moen et al. 1997; Rempel and Rodgers 1997). The 95\% CEP value is determined by graphically locating all data points located in the 95th percentile.

GPS Location Accuracy on Animals. Most studies conducted on new-technology GPS collars have examined location accuracy, two-dimensional (2D) verses three-dimensional (3D) locations, factors affecting accuracy and success rate, and performance under various cover types. Evaluation and testing are important because researchers require some level of confidence in a new system before general technology adaptation.

Moen et al. (1997) reported that for open canopy conditions, uncorrected readings from a GPS collar had a 50\% CEP of $28.2 \mathrm{~m}$ and a $95 \%$ CEP of $73.7 \mathrm{~m}$. These same readings with DGPS gave values of $4 \mathrm{~m}$ at $50 \%$ CEP and $10.6 \mathrm{~m}$ at 95\% CEP. They also noted that accuracy was not affected by heavy rain. Rempel and Rodgers (1997) found that under open canopy $95 \%$ of uncorrected readings had errors less than $125.6 \mathrm{~m}$. With DGPS, the $95 \%$ CEP was reduced to $7.5 \mathrm{~m}$.

Moen et al. (1996b) showed increased time-to-location fix with increased density of forest cover. Rempel and Rodgers (1997) verified decreased accuracy of both DGPS and non-DGPS locations with increased canopy cover. They also demonstrated a reduced rate of successful GPS location fixes with increased density of tree cover. The overall success-rate of signal acquisition has increased from $71 \%$ to 89\% (Rempel et al. 1995).

Moen et al (1996b) studied moose movement and habitat use on collar performance to assess the effects of a GPS receiver collar being worn by an animal. They found no correlation between moose movement and any of the following: proportion of 2D, 3D or failed location attempts; time to location fix; and higher dilution of precision for either $2 \mathrm{D}$ or 3D locations. They observed that fix success rate was related to ambient temperature where moose use cooler, denser vegetation in warmer weather.

GPS and GIS Applications in Domestic Animal Research Limited studies have examined GPS receiver performance on animals, mostly wildlife in the field. One study in Wales tracked sheep with GPS to correlate higher cesium levels in carcasses of animals that had grazed in specific areas (Roberts et al. 1995; Rutter et al. 1997). Success in tracking was obtained at the expense of a bulky pannier pack on each animal. Before DGPS, 95th percentile errors were $57.8 \mathrm{~m}$. After DGPS, errors were within $3.9 \mathrm{~m}$ of true location. The authors commented that "GPS with differential correction... is the only existing tracking/navigation system which has the potential to meet (horizontal accuracy) requirements." Hulbert et al. (1998) reported that 8 of 16 Scottish Blackface ewes were fitted with GPS collars weighing $863 \mathrm{~g}$, representing $2.2 \%$ of body weight. No differences between circadian rhythm and bite rate were found between the two sets of animals.

Geographic information systems have been used to map range usage (Beaver and Olson 1997). Beaver and Olson (1997) used GIS to map locations of thermal protection and compared extensive range use for older versus younger cattle through visual tracking. Wade et al. (1998) used GIS to model spatial distribution of beef cattle.

Beef cattle have been monitored using GPS collars in a grazing setting (Udal 1998; Udal et al. 1998). Assessment of GPS collar suitability with post-processed DGPS to track grazing cattle has been a focus of this research. Differentially corrected GPS technology and a lightweight unit suitable for grazing beef cows were required for this research application. Tracking requirements specified a system that would provide:

- Pasture location tracking of a mobile grazing cow;

- $5 \mathrm{~m}$ horizontal accuracy in locating true cow position;

- Continuous location fixes for a 5-d period;

- Frequency of location fixes to accurately track and map cow movement in pasture;

- Location fixes obtained regardless of weather, season, temperature, time or resources;

- Flexible and accessible parameter settings to optimize system, and;

- Convenient data access and easily analyzed.

\section{MATERIALS AND METHODS}

The goals of this project were to: 1) gather GPS data from grazing beef cows; 2) differentially correct; 3 ) spatially reference; 4) query the database; and 5) analyze data to allow interpretation.

Project resources included paddock, beef cattle, seven GPS tracking collars, and supporting software. The rectangular paddock (Fig. 1) was 6.07 ha (221 by 274 m). Forage was predominantly endophyte-infected tall fescue, with white clover, bluegrass, and alfalfa, but few weed species. Eight mature Angus and Angus-cross cows weighing up to $680 \mathrm{~kg}$ and nursing calves were used. Varying numbers of grazing steers (up to 16) were present at different times dur- 


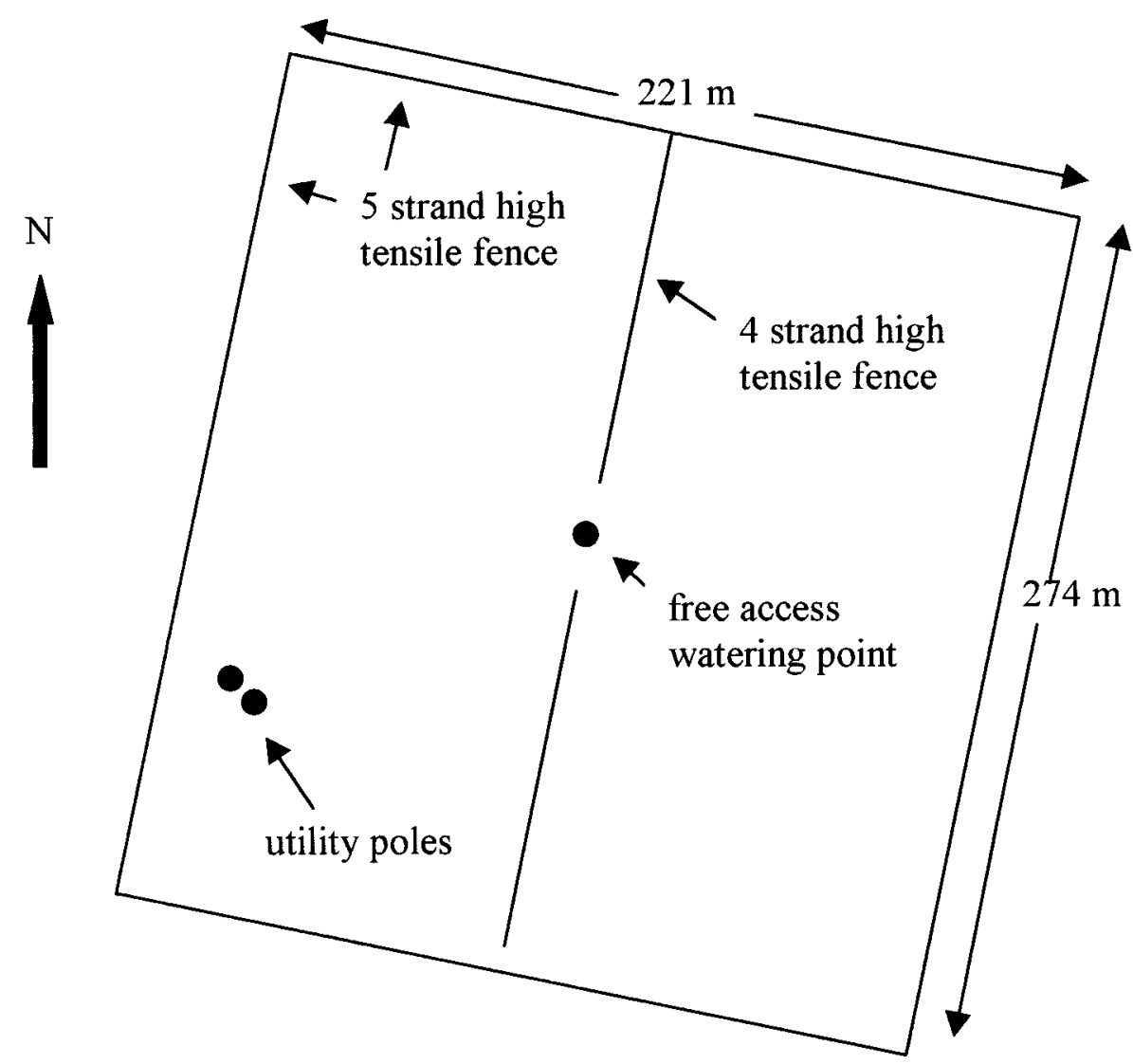

Fig. 1. Diagram of paddock layout. ing the grazing season, depending upon forage availability. All data collections were initiated with seven collared cows. GPS Collars. Collars were GPS_2000 small animal location system units (Lotek Engineering Inc., Newmarket, ON). Collars used a Motorola GPS engine in an eight-channel receiver, allowing signal lock on eight satellites simultaneously. Location information (latitude and longitude) was stored cumulatively in on-board RAM sufficient in size for 4400 position fixes. Each fix record contained corresponding height estimate, GPS date and time, dilution of precision value, fix status (2D or 3D), ID numbers of satellites used, ambient temperature, plus vertical and horizontal activity sensor counts. User-selectable position fix interval times available were $5,10,15,20$, and $30 \mathrm{~min}$ or $1,2,3,4$ and 6 h. The non-rechargeable power supply was a battery pack of high-density lithium cells that supports data collection up to $10 \mathrm{~d}$ at 5-min fix intervals. Collar units were compact, robust, and weighed less than $1 \mathrm{~kg}$. Figure 2 illustrates a GPS collar on a cow in the paddock.

Collars were fitted with two additional sensor types: 1) a temperature sensor records ambient temperature $\left( \pm 1^{\circ} \mathrm{C}\right)$ per GPS location fix. The sensor is not directly exposed and may display lag time in response to rapid temperature changes. 2) dual axis motion sensors record animal movement, and are sensitive to horizontal and vertical movements of the head and neck. They record activity in movement counts (255 counts maximum) that are stored with other information when GPS position fix is taken, then are reset to zero. The time period during which sensors record movement during each fix interval are user defined, but have an upper limit of 1 min less than the associated GPS fix interval setting. Two-way data transfer between THE collar unit and THE personal computer was facilitated by a hardware download link unit and associated proprietary software (Lotek Engineering Inc).

Collar attachment was accomplished within a few minutes per cow while the cow was confined in a squeeze chute. Animals were uniquely marked with non-permanent luminous ink marker to aid distant visual identification.

Differential GPS. Data collected from GPS collars were manipulated using a proprietary program designed to differentially correct position fix data for increased accuracy. A Trimble Community base station (Ag Data Weather Center, University of Kentucky) provided data at 5-s intervals in Trimble proprietary format (*.ssf). Files were converted to RINEX format (Receiver Independent Exchange) with a Trimble program (SSFRNX.exe) that gave position in latitude and longitude. A program (CORPSCON.exe, v4.12, U.S Army Topographic Engineering Center, internet freeware) was used to convert latitude and longitude values to the UTM (Universal Transverse Mercator) coordinate system. All GIS display and analyses were performed using ArcView GIS v3.0. 


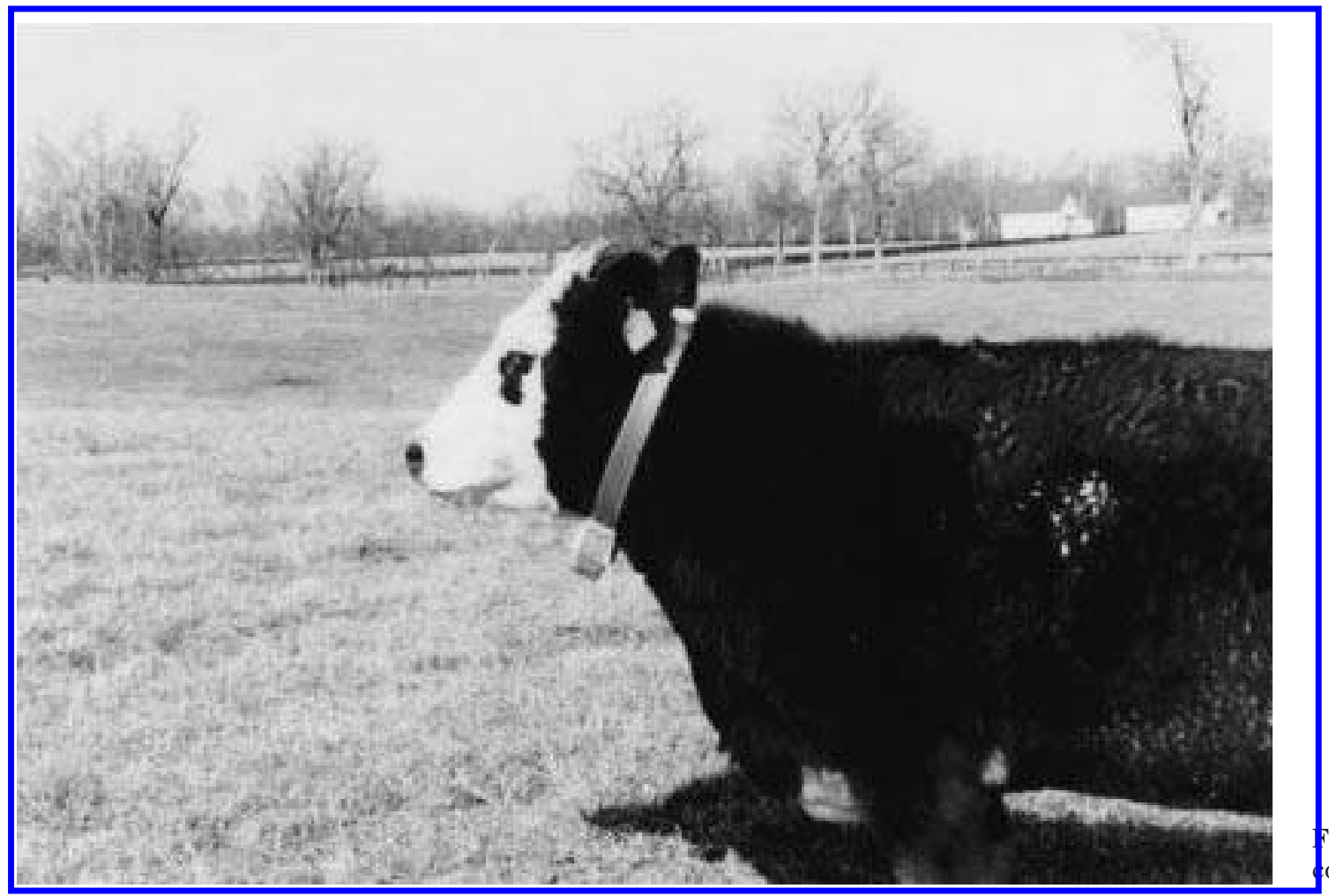

ig. 2. Cow with GPS ollar in paddock.

Static Accuracy. Data were collected from a collar (April 1997) to assess static accuracy. The collar was placed on a wooden cradle with antenna centered $1 \mathrm{~m}$ above a known longitude/latitude benchmark. Readings were taken at 5-min intervals for $24 \mathrm{~h}(1100 \mathrm{~h}, 16 \mathrm{th}-1100 \mathrm{~h}, 17 \mathrm{th})$. Statistical analysis (CEP) was applied to determine the error-of- location estimates. Rayleighs test was used to check for angular bias of error locations (Zar 1984).

GPS Data Collection and Analysis. Three cattle data collections were conducted: 1) November 1997 (1500 h, 21st 1300 h, 25th); 2) May 1998 (1500 h, 14th - 1200 h, 21st); and September 1998 (0000 h, 11th - 0800, 18th). The GPS fix interval was set at $5 \mathrm{~min}$ for each data collection. Data from five of seven collars were available for analysis from each collection. Reasons for incomplete data collection included failure of the collar to initiate and collect data, collar malfunction during collection and inability to download data.

The paddock was divided into a 16-cell (four $\times$ four) symmetrical grid (55.3 by 68.5 m, 0.378 ha each, Fig. 3). Pasture utilization, measured by time spent in each paddock grid section, was used as comparative measure between different collar strategies. Utilization per cell was indicated by number of locations (GPS fixes) within cell multiplied by GPS fix interval. Cell utilization was determined for period and expressed as a percentage of total paddock occupancy time. This percentage was used to compare among cells the effect of different GPS fix intervals or optimum number of animals collared.

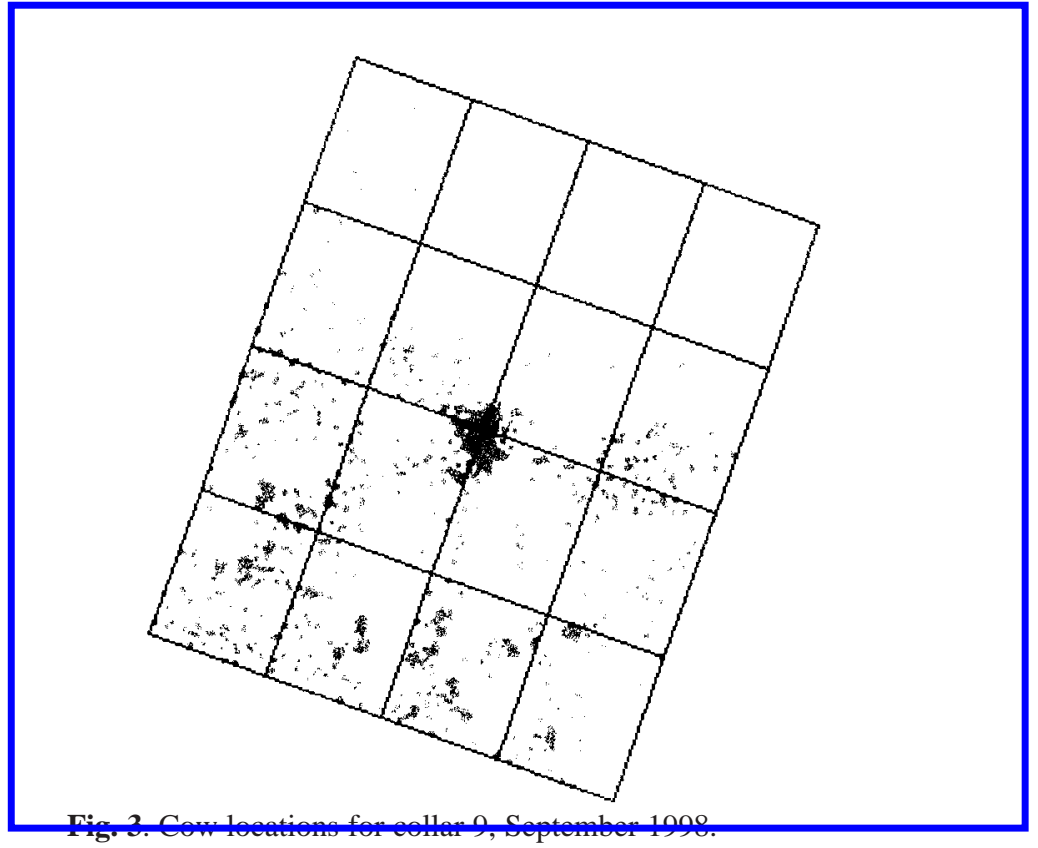

Five-minute fix interval utilization percentages were considered the control value against which other fix intervals were compared. Effects on pasture utilization by increasing GPS fix interval from 5 to-10 min was simulated by considering every second data record. Simulated 10-min records of location were selected and analyzed for distribution within the cells of the grid. The difference between the 5 and 10- 


\begin{tabular}{|c|c|c|c|c|c|}
\hline \multirow[b]{2}{*}{ Test date } & \multicolumn{5}{|c|}{ GPS fix interval, min } \\
\hline & 5 & 10 & 15 & 20 & 30 \\
\hline \multirow[t]{2}{*}{ November 1997} & 0 & 2.9 & 4.5 & 5.7 & 7.3 \\
\hline & 0 & 1.4 & 2.3 & 2.8 & 3.8 \\
\hline \multirow[t]{2}{*}{ May 1998} & 0 & 2.4 & 3.4 & 5.0 & 5.6 \\
\hline & $\mathbf{0}$ & 1.7 & 1.7 & 2.5 & 4.3 \\
\hline \multirow[t]{2}{*}{ September 1998} & 0 & 1.9 & 3.8 & 4.1 & 6.6 \\
\hline & $\mathbf{0}$ & 0.6 & 2.7 & 2.2 & 3.9 \\
\hline \multirow[t]{2}{*}{ Average } & 0 & 2.4 & 3.9 & 5.0 & 6.5 \\
\hline & $\mathbf{0}$ & 1.2 & 2.2 & 2.5 & 4.0 \\
\hline
\end{tabular}

min utilization was considered the error introduced by increasing the interval. Similar analyses were conducted for simulated GPS fix intervals of greater length.

Data analysis to represent the optimum proportion of collared herd was similar to GPS fix frequency analysis. Utilization per cell was known for the complete set of five collars. Four collars to represent data from the original five were simulated by removing all records for one collar in all possible combinations and weighting the remaining collar records by $5 / 4$. The resulting change was interpreted as the error introduced to pasture utilization by using the four-collar model instead of five collars. Errors within cells were weighted according to time of cell occupancy, which recognized greater effect of error in heavily utilized cells and lesser importance of error in cells less-utilized. A similar procedure was used for each reduction in collars down to one collar of the original five.

Animal Activity Analysis. Accurate prediction of animal activity for collared periods may enhance interpretation of animal forage utilization/intake relative to pasture location. Previously, collar capabilities were limited to animal location without indication of active grazing. A companion investigation was conducted to validate animal activity (grazing, standing, lying) based upon analysis of data from collar activity sensors. The success of this approach was limited in a study on moose (Moen et al. 1996a).

The GPS location fixes were taken every 5 min for $7 \mathrm{~d}$ where the activity-sampling window was set at $4 \mathrm{~min}$ between fixes. Cows were distantly observed on four occasions, each lasting up to 8 consecutive hours. At each GPS location fix, the general behavior of each cow during the preceding 5 min was classified as active (grazing) or inactive (standing or lying). Counts from horizontal and vertical activity sensors were summed for respective 4-min observation windows and data were analyzed for differences between collars and observed activity per period. An activity counter cutoff value was determined via trial and error that classified the activity of animals. These data were checked against observed data to evaluate the accuracy of this approach.

$\begin{aligned} & \text { Table 2. Average percentage error associated with paddock cell use as } \\
& \text { number of collars/herd (5 head) is reduced }\end{aligned}$
\begin{tabular}{lcc}
\hline Number of collars & Error & Range $( \pm)$ \\
\hline Five & 0 & 0 \\
Four & 9.7 & 5.4 \\
Three & 14.9 & 13.0 \\
Two & 22.4 & 19.5 \\
One & 38.9 & 21.7 \\
\hline
\end{tabular}

Computer Animation of GPS Data. Behavioral information may remain hidden in static representation of animal positions. Therefore, sequential maps of animal locations for a time period may contain useful information about animal and herd behavior or response to external stimuli. For example, animal observations may include time of day, ambient temperature, and their interactions related to shade presence, grazing pattern and social interaction. A script was developed in MATLAB (Udal 1998) to sequentially animate the location of animals, updating animal position on command. This allowed halting animation and visually assessing data at any point. The script animated ambient temperature data for corresponding GPS location fix, which correlated time of animal movement with temperature change.

\section{RESULTS AND DISCUSSION}

Static Test

Collar static testing showed that location fixes over a $24-\mathrm{h}$ period were accurate at approximately $8 \mathrm{~m} 95 \%$ of the time after differential correction. Errors had no directional bias, which is consistent with the findings of other studies.

\section{Fix Interval}

Increasing GPS fix interval from 5 to 30 min introduced proportionally increasing errors compared with original 5-min results (Table 1). However, errors were small (approximately 7\%) for a GPS fix interval of 30 min with a single animal. Errors introduced for multiple animals collared (4\%), are approximately two-thirds that of a single animal. The proposed study objectives should be carefully reviewed when choosing the length of the fix interval. Any interval greater than 5 min may overlook data apart from pasture utilization, such as discrete watering events or interpreting animal activity.

\section{Collar Number}

Significant errors were introduced when fewer collars were used to model locations of more animals (Table 2). These errors ranged from $10 \%$ when four of five cows were collared compared to nearly $40 \%$ when only one of five cows was collared. The range of error was approximately $70 \%$ of the average error values, indicating large animal variability. When fewer collars were used, average error and range of error increased. Expressed animal individuality yielded unique individual tracking patterns in the relatively small, intensively managed paddock. The researcher must ultimately determine the acceptable error in the research. 


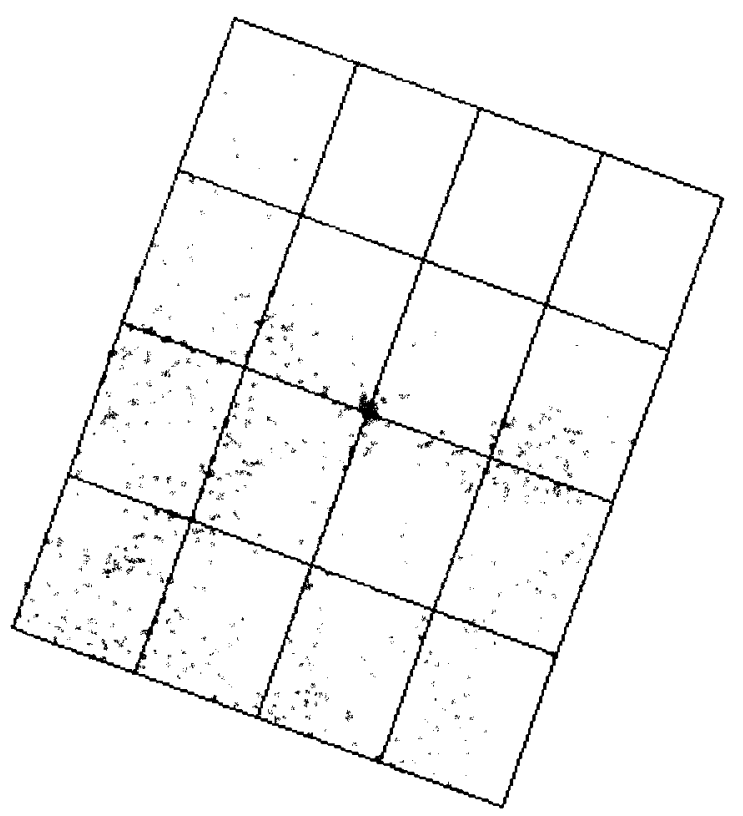

Fig. 4. Active (grazing) cow locations for collar 9, September 1998.

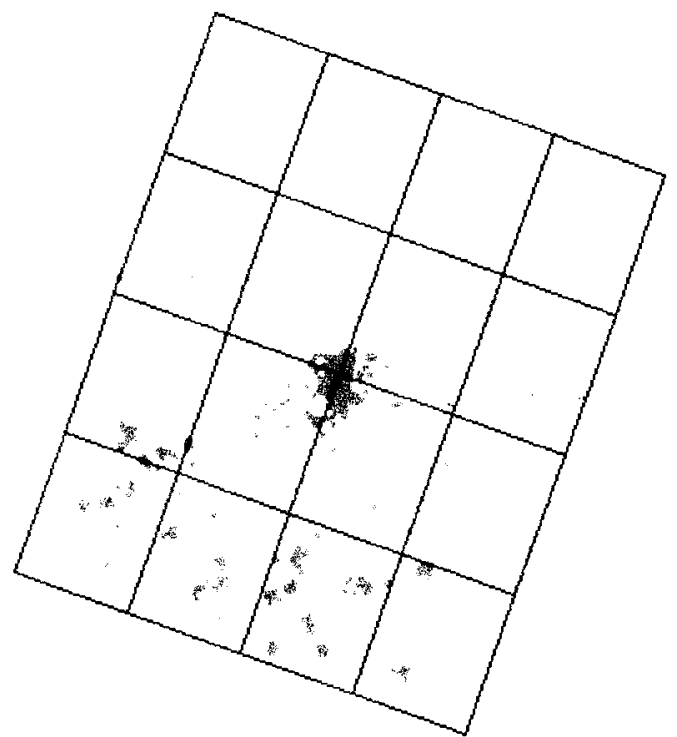

Fig. 5. Inactive (non-grazing) cow locations for collar 9, September 1998.

\section{Grazing versus Non-Grazing Behavior}

Differences were found between collars for activity sensor counts for the same observed behavior. This implies that mounting of collars per animal should be standardized (freedom of movement) and that individual collars may need to be calibrated. However, observed active verses inactive sensor count means were different $(P \leq 0.0001)$, suggesting that successful classification of activity counts occurred. A cutoff value of 200 was determined for sums of horizontal and vertical activity sensor counts. Animal sensor count sums (during 4-min periods between GPS fixes) less
Table 3. Estimated percentage of time spent grazing for each collar September 1998

\begin{tabular}{cc}
\hline Collar number & Percentage of time spent grazing $(\%)$ \\
\hline 19 & 31.6 \\
18 & 33.4 \\
17 & 33.5 \\
9 & 32.9 \\
4 & 19.7 \\
\hline
\end{tabular}

than 200 were classified as inactive, while sums equal to or greater than 200 were regarded as active.

This system correctly classified $94.8 \%(128 / 135)$ of active (grazing) data records, and 91.2\% (1092/1196) inactive (not grazing) data records for an overall performance of $91.7 \%(1220 / 1331)$ of records correctly classified. This high percentage of correct classification imparts confidence that accurate prediction of animal activity was accomplished. The GIS database was queried to visually demonstrate total, active, and inactive points over the entire period of the September study (Figs. 3, 4 and 5). Grazing location fixes in active classification were relatively well distributed. Inactive fixes (lying and standing behavior) were clustered, located near water or in favorite resting places.

Active verses inactive classifications in data were used to estimate the amount of time of "grazing" for each animal (Table 3). Four of five collars have grazing estimates within two percent $( \pm 0.9)$. These predictions correspond with literature estimates (McDaniel and Roark 1956). The Collar 4 estimate of grazing time was $60 \%$ that of other collars. This is most likely the result of misclassification of data points and not less time spent grazing, which illustrates the danger of applying activity classification to collars demonstrated to be different from each other. However, results for remaining collars display exciting potential for studies requiring identification of grazing behavior.

\section{Animation of Animal Movement}

Animation of data using MATLAB (The MathWorks, Inc., Natick, MA) is a useful approach to show time-related behavioral patterns. Figure 6 represents a traced illustration of three cows' movements for 14 May 1998, from $1500 \mathrm{~h}$ to $0000 \mathrm{~h}$, with location fixes taken at 5-min intervals. Initially, each animal was inactive and located near a watering point in the middle of the paddock. The corresponding ambient temperature for this time was 30 to $35^{\circ} \mathrm{C}$. The temperature began to drop at approximately $1800 \mathrm{~h}$, and cows sequentially moved from water within a half-hour, presumably to start grazing. The cows continued to graze as the temperature decreased to $17^{\circ} \mathrm{C}$ at $2145 \mathrm{~h}$, when the temperature began to rise. All cows began a resting period that lasted until $0000 \mathrm{~h}$. The patterns displayed in animation revealed interactions between individual cows and that individual cow movement may be influenced by ambient temperature. Similar patterns are found throughout the May data set. Beginning groundwork and methodology have been demonstrated for time-sequenced studies of behavioral response to environment, and potential exists for continuing research in this area. 


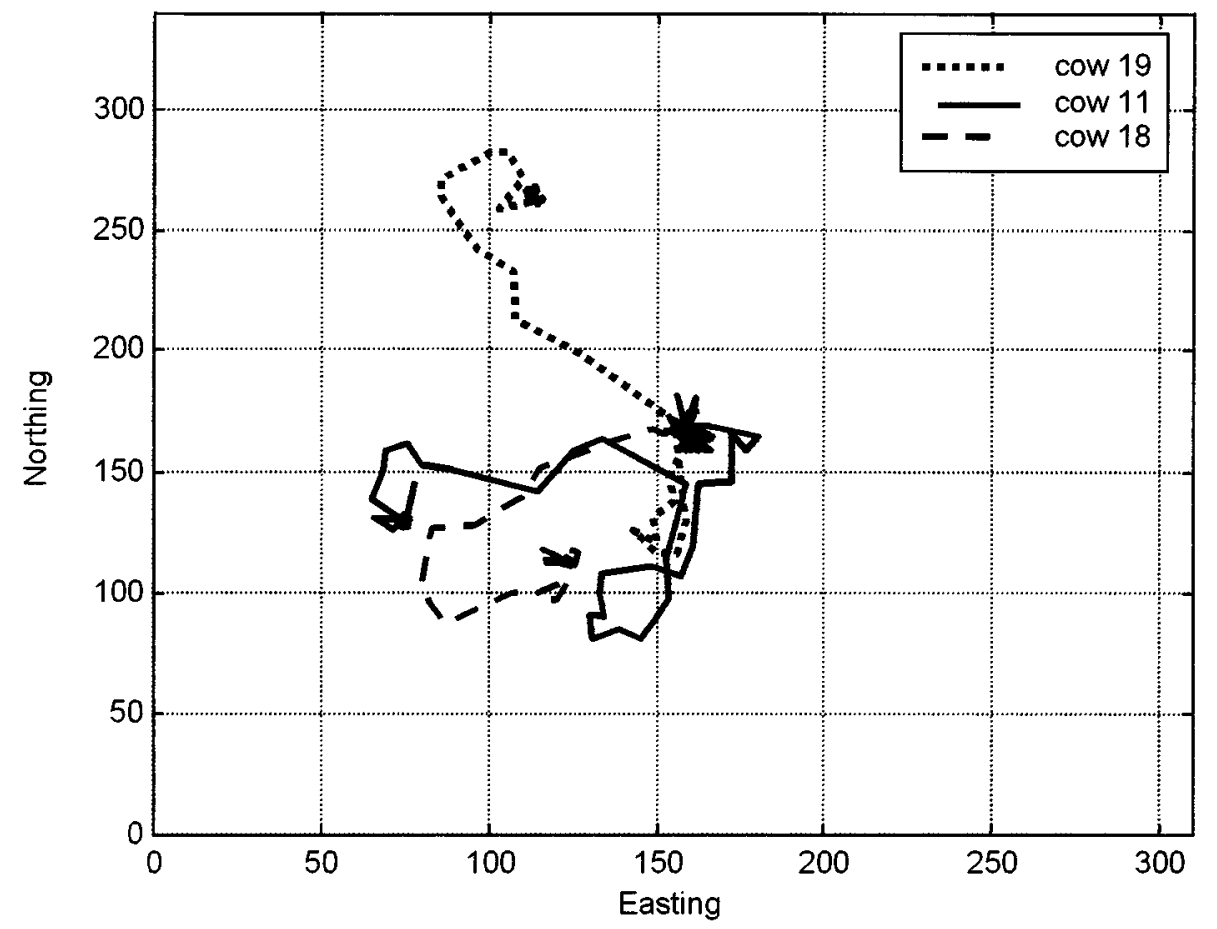

Fig. 6. Cow movement for collars 19, 18, and 11. 14 May 1998,1500 to $0000 \mathrm{~h}$.

\section{CONCLUSIONS}

Animal tracking and monitoring technology has advanced dramatically the past $50 \mathrm{yr}$. Progress from visual observation, to VHF radio transmitters, to satellite-based systems such as ARGOS and Navstar GPS has been dramatic. Advantages and disadvantages are associated with the use of each system. However, the GPS system matches or exceeds the benefits of any other method, with few disadvantages. The cost of GPS collar technology will reduce as this technology evolves and is marketed to a wider audience. A second challenge will be to utilize "real time" GPS location fixes for management. This technology currently exists in non-differentially corrected form for animal tracking. Corrected, "real-time" methods need to be developed.

Information reported here (length of GPS fix interval, number of collars required to represent a herd of grazing animals, classification of animal activity, and sequential animation of cow GPS locations) was gathered from grazing beef cows to investigate the quality and properties of GPSrelated data. These data suggested that there were definite grazing preferences exhibited by individual cows on pasture. Collar application parameters and performance characteristics have undergone preliminary investigation. Standardized collar mounting and calibration procedures will need documentation, allowing for effective data collection from future experiments in this research area.

\section{IMPLICATIONS}

Many environmental and management variables affect the distribution of grazing cattle on pasture. It will be necessary to understand the impact of these variables on cattle behav- ior and subsequent performance to maximize efficiency of pasture systems. Important variables include composition, availability, and distribution of forage; strategic location of shade, water, and supplemental feed; and pasture soil type, slope, and aspect. Furthermore, manipulation of management variables such as paddock shape and size, fence design, and different grazing systems have potential to affect grazing cattle efficiency. The effect of pasture size upon GPS collaring technology should be investigated. Cattle in small, familiar, intensively managed paddocks may exhibit different herd behavior than those in extensive rangeland grazing situations. Extensive grazing systems may require different cow collaring protocols. Collared dominant or social cows may represent herd location adequately and herd behavior may be estimated. Fenceless paddocks employing "real time" GPS systems to guide animal behavior pose an exciting opportunity. Monitoring livestock with GPS technology offers meaningful data from which research-based results can be obtained to improve such efforts.

\section{ACKNOWLEDGMENTS}

The authors wish to acknowledge the staff at the University of Kentucky Animal Research Center, especially Bruce Hightshoe and Jeff Greenwell, who provided able assistance with animal management. Ronnie Paul deserves special mention for his help, insights and experience in handling the animals. The help of Rick Wells in gathering data is gratefully acknowledged. Finally, we wish to acknowledge support of the University of Kentucky Agricultural Experiment Station. 
Argos. 1984. Location and data collection satellite system: user's guide. Service Argos, Toulouse, France. 36 pp.

Ballard, W. B. 1997. Unpublished paper. [Online] Available: http://degaulle.hil.unb.ca/UNB/forestry/focus.asc.

Beaver, J. M. and Olson, B. E. 1997. Winter range use by cattle of different ages in southwestern Montana. Appl. Anim. Behavior Sci. 51: 1-13.

Blackshaw, J. K. and Blackshaw, A. W. 1994. Heat stress in cattle and the effect of shade on production and behaviour: a review. Aust. J. Exp. Agric. 34: 285-295.

Buffington, D. E., Collier, R. J., and Canton, G. H. 1983. Shade management systems to reduce heat stress for dairy cows in hot, humid climates. Trans. ASAE 26: 1798-1802.

Collier, R. J., Eley, R. M., Sharma, A. K., Pereira, R. M. and Buffington, D. E. 1981. Shade management in subtropical environment for milk yield and composition in Holstein and Jersey cows. J. Dairy Sci. 64: 844-849.

Dana, P. H. 1997. Unpublished paper. Global positioning system overview. University of Texas, Austin, TX. [Online] Available: http://wwwhost.cc.utexas.edu/ftp/pub/grg/gcraft/notes/ gps/gps.html.

Fuller, M. R., Levanon, N., Strikwerda, T. E., Seegar, W. S., Wall, J., Black, H. D., Ward, F. P., Howey, P. W. and Partelow, J. 1984. Feasibility of a bird-borne transmitter for tracking via satellite. Pages 1-6 in Proc. 8th Int. Symp. Biotelemetry. 6-12 May 1984, Dubrovnik, Yugoslavia.

Gibb, D. J., McAllister, T. A., Huisma, C. and Wiedmeier, R. 1998. Bunk attendance of feedlot cattle monitored with radio frequency technology. Can. J. Anim. Sci. 78: 701-710.

Harris, R. B., Fancy, S. G., Douglas, D. C, Garner, G. W., Amstrup, S. C, McCabe, T. R. and Pank, L. F. 1990. Tracking wildlife by satellite: current systems and performance. U.S Fish and Wildl. Serv., Fish Wildl. Tech. Rep. 30. 52 pp.

Hart, R. H., Bissio, J., Samuel, M. J. and Waggoner Jr., J. W. 1993. Grazing systems, pasture size, and cattle grazing behavior, distribution and gains. J. Range. Manage. 46: 81-87.

Hulbert, I. A. R., Wyllie, J. T. B., Waterhouse A., French, J. and McNulty, D. 1998. A note on the circadian rhythm and feeding behaviour of sheep fitted with a lightweight GPS collar. Appl. Anim. Behav. Sci. 60(4): 359-364.

Langbein, J. and Nichelmann, M. 1993. Differences in behavior of free-ranging cattle in the tropical climate. Appl. Anim. Behav. Sci. 37: 197-209.

Marlow, C. B., Pogacnik, T. M. and Quinsey, S. D. 1987. Streambank stability and cattle grazing in Southwestern Montana. J. Soil Water Conserv. 42: 291-296.

Mate, B. R., Beaty, D., Hoisington, C., Kutz, R. and Mate, M. L. 1983. Satellite monitoring of humpback whale diving behavior and movements. Unpublished progress report to Minerals Management Service. Alaska Outer Continental Shelf Program Office, Anchorage. 24 pp.

McDaniel, A. H. and Roark, C. B. 1956. Performance and grazing habits of Hereford and Aberdeen-Angus cows and calves on improved pastures as related to types of shade. J. Anim. Sci. 15: 59-63.
Mech, L. D. 1983. Handbook of animal radio tracking. University of Minnesota Press, Mineapolis, MN. 107 pp.

Moen, R., Pastor, J. and Cohen, Y. 1996a. Interpreting behavior from activity counters in GPS collars on moose. Alces 32: 101-108.

Moen, R. A., Pastor, J., Cohen, Y. and Schwartz, C. C. 1996 b. Effects of moose movement and habitat use on GPS collar performance. J. Wildl. Manage. 60: 659-668.

Moen, R., Pastor, J. and Cohen, Y. 1997. Accuracy of GPS telemetry collar locations with differential correction. J. Wildl. Manage. 61(2): 530-539.

Owens, M. K., Launchbaugh, K. L. and Holloway, J. W. 1991. Pasture characteristics affecting spatial distribution of utilization by cattle in mixed brush communities. J. Range Manage. 44: 118-123.

Pinchak, W. E., Smith, M. A., Hart, R. H. and Waggoner Jr., J. W. 1991. Beef cattle distribution patterns on foothill range. J. Range Manage. 44: 267-275.

Rempel, R. S. and Rodgers, A. R. 1997. Effects of differential correction on accuracy of a GPS animal location system. J. Wildl. Manage. 61: 525-530.

Rempel, R. S., Rodgers, A. R. and Abraham, K. F. 1995. Performance of a GPS animal location system under boreal forest canopy. J. Wildl. Manage. 59: 43-551.

Roberts, G., Williams, A., Last, J. D., Penning, P. D. and Rutter, S. M. 1995. A low-power postprocessed DGPS system for logging the locations of sheep on hill pastures. Navigation: J. Inst. Navigation 42: 327-336.

Rodgers, A. R., Rempel, R. S. and Abraham, K. F. 1996. A GPS based telemetry system. Wildl. Soc. Bul. 24: 559-566.

Rutter, S. M., Beresford, N. A. and Roberts, G. 1997. Use of GPS to identify the grazing areas of hill sheep. Comput. Electron. Agric. 17: 177-188.

Smith, M. A., Rodgers, J. D., Dodd, J. L. and Skinner, Q. D. 1992. Habitat selection by cattle along an ephemeral channel. J. Range Manage. 45: 385-390.

Tchamba, M. N., Bauer, H. and de Iongh, H. H. 1995. Application of VHF-radio and satellite telemetry techniques on elephants in northern Cameroon. Afr. J. Ecol. 33: 335-346.

Udal, M. C. 1998. GPS tracking of cattle on pasture. Masters Thesis. University of Kentucky, Lexington, KY.

Udal, M. C., Turner, L. W., Larson, B. T. and Shearer, S. A. 1998. GPS tracking of cattle on pasture. ASAE Paper No. 983134. Int. Meet. ASAE. Orlando, FL. 12-15 July.

Wade, T. G., Schultz, B. W., Wickham, J. D. and Bradford, D. F.1998. Modeling the potential spatial distribution of beef cattle grazing using a Geographic Information System. J. Arid. Environ. 38(2): 325-334.

Zar, J. H. 1984. Biostatistical analysis. 2nd ed. Prentice Hall, Englewood Cliffs, NJ. 718 pp. 



\section{This article has been cited by:}

1. Samuel A. Wyffels, Mark K. Petersen, Darrin L. Boss, Bok F. Sowell, Janice G.P. Bowman, Lance B. McNew. 2019. Dormant Season Grazing: Effect of Supplementation Strategies on Heifer Resource Utilization and Vegetation Use. Rangeland Ecology \& Management 72:6, 878-887. [Crossref]

2. Jason W. Karl, James E. Sprinkle. 2019. Low-Cost Livestock Global Positioning System Collar from Commercial Off-the-Shelf Parts. Rangeland Ecology \& Management 72:6, 954-958. [Crossref]

3. Jehan-Antoine Vayssade, Rémy Arquet, Mathieu Bonneau. 2019. Automatic activity tracking of goats using drone camera. Computers and Electronics in Agriculture 162, 767-772. [Crossref]

4. Francisco Maroto-Molina, Jorge Navarro-García, Karen Príncipe-Aguirre, Ignacio Gómez-Maqueda, José E. Guerrero-Ginel, Ana Garrido-Varo, Dolores C. Pérez-Marín. 2019. A Low-Cost IoT-Based System to Monitor the Location of a Whole Herd. Sensors 19:10, 2298. [Crossref]

5. Thuy Doan, Xulin Guo. 2019. Understanding Bison Carrying Capacity Estimation in Northern Great Plains Using Remote Sensing and GIS. Canadian Journal of Remote Sensing 45:2, 139-162. [Crossref]

6. Luís Nóbrega, Paulo Pedreiras, Pedro Gonçalves. SheepIT, an IoT-Based Weed Control System 131-147. [Crossref]

7. Pradeep Wagle, Prasanna H. Gowda, Brian K. Northup, Patrick J. Starks, James P. S. Neel. 2019. Response of Tallgrass Prairie to Management in the U.S. Southern Great Plains: Site Descriptions, Management Practices, and Eddy Covariance Instrumentation for a Long-Term Experiment. Remote Sensing 11:17, 1988. [Crossref]

8. Khamphou Phouyyavong, Shinsuke Tomita, Satoshi Yokoyama. 2019. Impact of forage introduction on cattle grazing practices and crop-livestock systems: a case study in an upland village in northern Laos. The Rangeland Journal 41:4, 323. [Crossref]

9. Roberta Aparecida Carnevalli, Andrea Cristina Tavares de Mello, Luciano Shozo, Steben Crestani, Admar Junior Coletti, Camila Eckstein. 2019. Spatial distribution of dairy heifers' dung in silvopastoral systems. Ciência Rural 49:10. . [Crossref]

10. Christopher Cheleuitte-Nieves, Humberto L. Perotto-Baldivieso, X. Ben Wu, Susan M. Cooper. 2018. Association patterns reveal dispersal-aggregation dynamics among cattle in a South Texas Rangeland, USA. Ecological Processes 7:1. . [Crossref]

11. Devan Allen McGranahan, Benjamin Geaumont, Jonathan W. Spiess. 2018. Assessment of a livestock GPS collar based on an open-source datalogger informs best practices for logging intensity. Ecology and Evolution 8:11, 5649-5660. [Crossref]

12. Derek W Bailey, Mark G Trotter, Colt W Knight, Milt G Thomas. 2018. Use of GPS tracking collars and accelerometers for rangeland livestock production research1. Translational Animal Science 2:1, 81-88. [Crossref]

13. João Serrano, E. Sales-Baptista, Shakib Shahidian, J. Marques da Silva, I. Ferraz de Oliveira, J. Lopes de Castro, Alfredo Pereira, M. Cancela d'Abreu, Mário de Carvalho. 2018. Proximal sensors for monitoring seasonal changes of feeding sites selected by grazing ewes. Agroforestry Systems 14. . [Crossref]

14. Dominique Van der Saag, Peter White, Lachlan Ingram, Jaime Manning, Peter Windsor, Peter Thomson, Sabrina Lomax. 2018. Effects of Topical Anaesthetic and Buccal Meloxicam Treatments on Concurrent Castration and Dehorning of Beef Calves. Animals 8:3, 35. [Crossref]

15. Saravanan K., Saraniya S.. 2018. Cloud IOT based novel livestock monitoring and identification system using UID. Sensor Review 38:1, 21-33. [Crossref]

16. E.D. Ungar, Y. Nevo, H. Baram, A. Arieli. 2017. Evaluation of the Ice Tag leg sensor and its derivative models to predict behaviour, using beef cattle on rangeland. Journal of Neuroscience Methods . [Crossref]

17. Eloise Zimbelman, Robert Keefe, Eva Strand, Crystal Kolden, Ann Wempe. 2017. Hazards in Motion: Development of Mobile Geofences for Use in Logging Safety. Sensors 17:4, 822. [Crossref]

18. B. Wolfger, B.W. Jones, K. Orsel, J.M. Bewley. 2017. Technical note: Evaluation of an ear-attached real-time location monitoring system. Journal of Dairy Science 100:3, 2219-2224. [Crossref]

19. Iris Schoenbaum, Jaime Kigel, Eugene D. Ungar, Amit Dolev, Zalmen Henkin. 2017. Spatial and temporal activity of cattle grazing in Mediterranean oak woodland. Applied Animal Bebaviour Science 187, 45-53. [Crossref]

20. Jaime K. Manning, Greg M. Cronin, Luciano A. González, Evelyn J.S. Hall, Andrew Merchant, Lachlan J. Ingram. 2017. The effects of global navigation satellite system (GNSS) collars on cattle ( Bos taurus) behaviour. Applied Animal Bebaviour Science 187, 54-59. [Crossref]

21. T. Gotoh, M. Maeda, O. Hirano, M. Nishiki, T. Fujita, T. Shibata, Y. Takayama, K. Yokoo, T. Nishidoi, H. Urabe, T. Ikenouchi, T. Ninomiya, M. Yoshida, J. Sugiyama, T. Sasaki, S. Sawane, A. Muranishi. 467. [Crossref] 
22. Andréia Cristina Tavares de Mello, Roberta Aparecida Carnevalli, Luciano Shozo Shiratsuchi, Bruno Carneiro e Pedreira, Luciano Bastos Lopes, Diego Batista Xavier. 2017. Improved grazing activity of dairy heifers in shaded tropical grasslands. Ciência Rural 47:2. . [Crossref]

23. Santosh Kumar, Sanjay Kumar Singh, Rishav Singh, Amit Kumar Singh. Analytical Study of Animal Biometrics: A Technical Survey 21-78. [Crossref]

24. Matteo Barcella, Federico Filipponi, Silvia Assini. 2016. A simple model to support grazing management by direct field observation. Agriculture, Ecosystems \& Environment 234, 107-117. [Crossref]

25. Xiaoyun Zhao. 2015. On processing GPS tracking data of spatio-temporal car movements: a case study. Journal of Location Based Services 9:4, 235-253. [Crossref]

26. Shengpan Lin, Mark H. DeVisser, Joseph P. Messina. 2015. An agent-based model to simulate tsetse fly distribution and control techniques: A case study in Nguruman, Kenya. Ecological Modelling 314, 80-89. [Crossref]

27. Frederick N. Bebe, Terry Hutchens, Kenneth M. Andries, Ken J. Bates, Terry Gipson, Myron Evans. 2015. Meat Goats in Hillside Pastures: Control of Undesirable Plant Species and GPS Collar Determination of Activity Patterns. Journal of the Kentucky Academy of Science 75:1-2, 69-79. [Crossref]

28. Nelleke de Weerd, Frank van Langevelde, Herman van Oeveren, Bart A. Nolet, Andrea Kölzsch, Herbert H. T. Prins, W. Fred de Boer. 2015. Deriving Animal Behaviour from High-Frequency GPS: Tracking Cows in Open and Forested Habitat. PLOS ONE 10:6, e0129030. [Crossref]

29. Patrick Kibambe Mashoko Nkwari, S. Rimer, B.S. Paul, H. Ferreira. Heterogeneous wireless network based on Wi-Fi and ZigBee for cattle monitoring 1-9. [Crossref]

30. Tanusri Bhattacharya, Lars Kulik, James Bailey. 2015. Automatically recognizing places of interest from unreliable GPS data using spatio-temporal density estimation and line intersections. Pervasive and Mobile Computing 19, 86-107. [Crossref]

31. Bradley Panckhurst, Phill Brown, Keith Payne, T. C. A. Molteno. Solar-powered sensor for continuous monitoring of livestock position 1-6. [Crossref]

32. Tong Liu, Angela R. Green, Luis F. Rodríguez, Brett C. Ramirez, Daniel W. Shike. 2015. Effects of Number of Animals Monitored on Representations of Cattle Group Movement Characteristics and Spatial Occupancy. PLOS ONE 10:2, e0113117. [Crossref]

33. Adeniran Ishola Oluwaranti, Seun Ayeni. 2015. Monocular Vision Based Boundary Avoidance for Non-Invasive Stray Control System for Cattle: A Conceptual Approach. Journal of Sensor Technology 05:03, 63-71. [Crossref]

34. Gail H. Collins, Steven L. Petersen, Craig A. Carr, Leon Pielstick. 2014. Testing VHF/GPS Collar Design and Safety in the Study of Free-Roaming Horses. PLoS ONE 9:9, e103189. [Crossref]

35. Greg Bishop-Hurley, Dave Henry, Daniel Smith, Ritaban Dutta, James Hills, Richard Rawnsley, Andrew Hellicar, Greg Timms, Ahsan Morshed, Ashfaqur Rahman, Claire D'Este, Yanfeng Shu. An investigation of cow feeding behavior using motion sensors 1285-1290. [Crossref]

36. R. C. Dobos, S. Dickson, D. W. Bailey, M. G. Trotter. 2014. The use of GNSS technology to identify lambing behaviour in pregnant grazing Merino ewes. Animal Production Science 54:10, 1722. [Crossref]

37. L. A. Gonz lez, G. Bishop-Hurley, D. Henry, E. Charmley. 2014. Wireless sensor networks to study, monitor and manage cattle in grazing systems. Animal Production Science 54:10, 1687. [Crossref]

38. Masaki Shirai, Satoshi Yokoyama. Grazing Behavior and Local Management of Cattle and Buffaloes in Rural Laos 63-84. [Crossref]

39. Christine E. Kaucner, Vicky Whiffin, James Ray, Martin Gilmour, Nicholas J. Ashbolt, Richard Stuetz, David J. Roser. 2013. Can off-river water and shade provision reduce cattle intrusion into drinking water catchment riparian zones?. Agricultural Water Management 130, 69-78. [Crossref]

40. Mikko Asikainen, Keijo Haataja, Pekka Toivanen. Wireless indoor tracking of livestock for behavioral analysis 1833-1838. [Crossref]

41. Krzysztof Adamczyk, Joanna Pokorska, Joanna Makulska, Bernadette Earley, Mickael Mazurek. 2013. Genetic analysis and evaluation of behavioural traits in cattle. Livestock Science 154:1-3, 1-12. [Crossref]

42. Fadzai M. Zengeya, Onisimo Mutanga, Amon Murwira. 2013. Linking remotely sensed forage quality estimates from WorldView-2 multispectral data with cattle distribution in a savanna landscape. International Journal of Applied Earth Observation and Geoinformation 21, 513-524. [Crossref]

43. David Augustine, Justin Derner. 2013. Assessing Herbivore Foraging Behavior with GPS Collars in a Semiarid Grassland. Sensors 13:3, 3711-3723. [Crossref] 
44. Dean M. Anderson, Rick E. Estell, Andres F. Cibils. 2013. Spatiotemporal Cattle Data-A Plea for Protocol Standardization. Positioning 04:01, 115-136. [Crossref]

45. T.A. Gipson, T. Sahlu, M. Villaquiran, S.P. Hart, J. Joseph, R.C. Merkel, A.L. Goetsch. 2012. Use of global positioning system collars to monitor spatial-temporal movements of co-grazing goats and sheep and their common guardian dog. Journal of Applied Animal Research 40:4, 354-369. [Crossref]

46. Z. Henkin, E. D. Ungar, A. Dolev. 2012. Foraging behaviour of beef cattle in the hilly terrain of a Mediterranean grassland. The Rangeland Journal 34:2, 163. [Crossref]

47. P.G. Dunne, F.J. Monahan, A.P. Moloney. 2011. Current perspectives on the darker beef often reported from extensively-managed cattle: Does physical activity play a significant role?. Livestock Science 142:1-3, 1-22. [Crossref]

48. João M. Serrano, José O. Peça, J. Marques da Silva, Shakib Shahidian. 2011. Calibration of a capacitance probe for measurement and mapping of dry matter yield in Mediterranean pastures. Precision Agriculture 12:6, 860-875. [Crossref]

49. Fadzai Zengeya, Amon Murwira, M. de Garine-Wichatitsky. 2011. An IKONOS-based comparison of methods to estimate cattle home ranges in a semi-arid landscape of southern Africa. International Journal of Remote Sensing 32:22, 7805-7826. [Crossref]

50. Bethany A. Bradley, Mary Tess O'sullivan. 2011. Assessing the short-term impacts of changing grazing regime at the landscape scale with remote sensing. International Journal of Remote Sensing 32:20, 5797-5813. [Crossref]

51. D. B. Taylor, D. A. Schneider, W. Y. Brown, I. R. Price, M. G. Trotter, D. W. Lamb, G. N. Hinch. 2011. GPS observation of shelter utilisation by Merino ewes. Animal Production Science 51:8, 724. [Crossref]

52. D. L. Swain, M. A. Friend, G. J. Bishop-Hurley, R. N. Handcock, T. Wark. 2011. Tracking livestock using global positioning systems - are we still lost?. Animal Production Science 51:3, 167. [Crossref]

53. Eugene D. Ungar, Iris Schoenbaum, Zalmen Henkin, Amit Dolev, Yehuda Yehuda, Arieh Brosh. 2011. Inference of the Activity Timeline of Cattle Foraging on a Mediterranean Woodland Using GPS and Pedometry. Sensors 11:1, 362-383. [Crossref]

54. Katja Polojärvi, Alfred Colpaert, Kenneth Matengu, Jouko Kumpula. GPS Collars in Studies of Cattle Movement: Cases of Northeast Namibia and North Finland 173-187. [Crossref]

55. A. Zerger, R.A. Viscarra Rossel, D.L. Swain, T. Wark, R.N. Handcock, V.A.J. Doerr, G.J. Bishop-Hurley, E.D. Doerr, P.G. Gibbons, C. Lobsey. 2010. Environmental sensor networks for vegetation, animal and soil sciences. International Journal of Applied Earth Observation and Geoinformation 12:5, 303-316. [Crossref]

56. Nariyasu Watanabe, Kazuhiro Umemura, Seiichi Sakanoue, Takaharu Kozakai, Kensuke Kawamura. 2010. Utilization by cattle of a pasture including aged hilly sections. Grassland Science 56:3, 160-167. [Crossref]

57. B. Butt. 2010. Seasonal space-time dynamics of cattle behavior and mobility among Maasai pastoralists in semi-arid Kenya. Journal of Arid Environments 74:3, 403-413. [Crossref]

58. Elisa Gottardi, Frédérique Tua, Bruno Cargnelutti, Marie-Line Maublanc, Jean-Marc Angibault, Sonia Said, Hélène Verheyden. 2010. Use of GPS activity sensors to measure active and inactive behaviours of European roe deer (Capreolus capreolus). mammalia 74:4. . [Crossref]

59. M. G. Trotter, D. W. Lamb, G. N. Hinch, C. N. Guppy. 2010. Global navigation satellite system livestock tracking: system development and data interpretation. Animal Production Science 50:6, 616. [Crossref]

60. Kathy J. Soder, Pablo Gregorini, Guillermo Scaglia, Andrew J. Rook. 2009. Dietary Selection by Domestic Grazing Ruminants in Temperate Pastures: Current State of Knowledge, Methodologies, and Future Direction. Rangeland Ecology \& Management 62:5, 389-398. [Crossref]

61. D. H. Franklin, M. L. Cabrera, H. L. Byers, M. K. Matthews, J. G. Andrae, D. E. Radcliffe, M. A. McCann, H. A. Kuykendall, C. S. Hoveland, V. H. Calvert. 2009. Impact of water troughs on cattle use of riparian zones in the Georgia Piedmont in the United States1. Journal of Animal Science 87:6, 2151-2159. [Crossref]

62. Rebecca Handcock, Dave Swain, Greg Bishop-Hurley, Kym Patison, Tim Wark, Philip Valencia, Peter Corke, Christopher O’Neill. 2009. Monitoring Animal Behaviour and Environmental Interactions Using Wireless Sensor Networks, GPS Collars and Satellite Remote Sensing. Sensors 9:5, 3586-3603. [Crossref]

63. Bilal Butt, Ashton Shortridge, Antoinette M.G.A. WinklerPrins. 2009. Pastoral Herd Management, Drought Coping Strategies, and Cattle Mobility in Southern Kenya. Annals of the Association of American Geographers 99:2, 309-334. [Crossref]

64. N. W. Tomkins, P. J. O'Reagain, D. Swain, G. Bishop-Hurley, E. Charmley. 2009. Determining the effect of stocking rate on the spatial distribution of cattle for the subtropical savannas. The Rangeland Journal 31:3, 267. [Crossref]

65. Koji Yamazaki, Chinatsu Kozakai, Shinsuke Kasai, Yusuke Goto, Shinsuke Koike, Kengo Furubayashi. 2008. A Preliminary Evaluation of Activity-Sensing GPS Collars for Estimating Daily Activity Patterns of Japanese Black Bears. Ursus 19:2, 154-161. [Crossref] 
66. Chinatsu Kozakai, Shinsuke Koike, Koji Yamazaki, Kengo Furubayashi. 2008. Examination of captive Japanese black bear activity using activity sensors. Mammal Study 33:3, 115-119. [Crossref]

67. Steve Warren, Angel Martinez, Timothy Sobering, Daniel Andresen. Electrocardiographic pill for cattle heart rate determination 4852-4855. [Crossref]

68. Dorothee Putfarken, Jürgen Dengler, Stephan Lehmann, Werner Härdtle. 2008. Site use of grazing cattle and sheep in a largescale pasture landscape: A GPS/GIS assessment. Applied Animal Behaviour Science 111:1-2, 54-67. [Crossref]

69. D. W. Bailey, H. C. VanWagoner, R. Weinmeister, D. Jensen. 2008. Comparison of low-moisture blocks and salt for manipulating grazing patterns of beef cows. Journal of Animal Science 86:5, 1271-1277. [Crossref]

70. Mac Schwager, Dean M. Anderson, Zack Butler, Daniela Rus. 2007. Robust classification of animal tracking data. Computers and Electronics in Agriculture 56:1, 46-59. [Crossref]

71. Derek W. Bailey, G. Robert Welling. 2007. Evaluation of Low-Moisture Blocks and Conventional Dry Mixes for Supplementing Minerals and Modifying Cattle Grazing Patterns. Rangeland Ecology \& Management 60:1, 54-64. [Crossref]

72. N. Tomkins, P. O'Reagain. 2007. Global positioning systems indicate landscape preferences of cattle in the subtropical savannas. The Rangeland Journal 29:2, 217. [Crossref]

73. D. M. Anderson. 2007. Virtual fencing - past, present and future. The Rangeland Journal 29:1, 65. [Crossref]

74. M. Barbari, L. Conti, B.K. Koostra, G. Masi, F. Sorbetti Guerri, S.R. Workman. 2006. The Use of Global Positioning and Geographical Information Systems in the Management of Extensive Cattle Grazing. Biosystems Engineering 95:2, 271-280. [Crossref]

75. Kevin Smith, Angel Martinez, Roland Craddolph, Howard Erickson, Daniel Andresen, Steve Warren. An Integrated Cattle Health Monitoring System 4659-4662. [Crossref]

76. C. M. H. Chantal Kurvers, P. René van Weeren, Chris W. Rogers, Machteld C. van Dierendonck. 2006. Quantification of spontaneous locomotion activity in foals kept in pastures under various management conditions. American Journal of Veterinary Research 67:7, 1212-1217. [Crossref]

77. MARIE-LOU COULOMBE, ARIANE MASSÉ, STEEVE D. CÔTÉ. 2006. Quantification and Accuracy of Activity Data Measured with VHF and GPS Telemetry. Wildlife Society Bulletin 34:1, 81-92. [Crossref]

78. M. Lachica, J.F. Aguilera. 2005. Energy expenditure of walk in grassland for small ruminants. Small Ruminant Research 59:2-3, 105-121. [Crossref]

79. Eugene D. Ungar, Zalmen Henkin, Mario Gutman, Amit Dolev, Avraham Genizi, David Ganskopp. 2005. Inference of Animal Activity From GPS Collar Data on Free-Ranging Cattle. Rangeland Ecology \& Management 58:3, 256-266. [Crossref]

80. Yasuhiro SUGIMOTO, Youhei MATUOKA, Kazuyuki MORIYA. 2005. Affect Transferring of Watering Place on the Home Range of Grazing Cattle in Forest. Nibon Chikusan Gakkaibo 76:1, 39-49. [Crossref]

81. Eva Schlecht, Christian Hülsebusch, Friedrich Mahler, Klaus Becker. 2004. The use of differentially corrected global positioning system to monitor activities of cattle at pasture. Applied Animal Bebaviour Science 85:3-4, 185-202. [Crossref]

82. DEREK W. BAILEY, MARTINA R. KEIL, LARRY R. RITTENHOUSE. 2004. Research observation: Daily movement patterns of hill climbing and bottom dwelling cows. Rangeland Ecology \& Management 57:1, 20-28. [Crossref]

83. Kazuyuki MORIYA, Tetsuhiko YOSHIMURA, Masayuki KITAGAWA, Masayuki OYAMADA, Yasuhiro SUGIMOTO. 2003. Monitoring Cattle Behavior in the Forest Using GPS Records. Nibon Chikusan Gakkaibo 74:2, 229-234. [Crossref]

84. S. Warren, L. Nagl, R. Schmitz, J. Yao, T. Hildreth, H. Erickson, D. Poole, D. Andresen. A distributed infrastructure for veterinary telemedicine 1394-1397. [Crossref]

85. L. Nagl, R. Schmitz, S. Warren, T.S. Hildreth, H. Erickson, D. Andresen. Wearable sensor system for wireless state-of-health determination in cattle 3012-3015. [Crossref]

86. S.A. Schoenig, T.S. Hildreth, L. Nagl, H. Erickson, M. Spire, D. Andresen, S. Warren. Ambulatory instrumentation suitable for long-term monitoring of cattle health 2379-2382. [Crossref] 